UMCS, Wydział Humanistyczny

Instytut Neofilologii

Katedra Literaturoznawstwa Słowiańskiego

tel.: + 48502211458

e-mail: gagozdek@gmail.com

ORCID ID: https://orcid.org/0000-0003-0888-2207

\title{
Antropologiczny aspekt pisarstwa Lidii Zinowjewej-Annibał. Obraz kobiety w dramacie Кольца
}

Słowa kluczowe: Lidia Zinowjewa-Annibał, Obraczki, symbolizm, kobieta, dramat

Rosyjska Diotyma - Lidia Zinowjewa-Annibał (1866-1907) - była postacią niewątpliwie nieprzeciętną na panteonie Srebrnego Wieku. Chociaż przez lata kojarzono ją przede wszystkim z rolą gospodyni „Baszni” i żony wielkiego poety Wiaczesława Iwanowa, to, jak podkreślają uczeni, była również, a może nawet przede wszystkim, utalentowaną pisarką i poetką. Jej niezbyt liczne, lecz oryginalne utwory przez długi czas nie przyciągały uwagi publiki czytelniczej i krytyków, co współcześni badacze próbują tłumaczyć następującymi faktami: po pierwsze - jej nagłą śmiercią, która dopadła ją niejako u progu nowych odkryć artystycznych; po drugie - cieniem męża - znanego i cenionego poety-symbolisty i wybitnego teoretyka symbolizmu, przysłaniającym jej dokonania; po trzecie wreszcie - jej zbliżeniem się do kręgu poetów i pisarzy, których twórczość w okresie sowieckim stała się ideologicznie niewłaściwa [Баркер 2001].

Tak czy owak, w świadomości współczesnych Zinowjewa-Annibał istniała (głównie za sprawą męża) przede wszystkim jako Menada, Bachantka, uczestniczka obrzędów dionizyjskich, nie zaś jako poetka i pisarka (choć sama rozpaczliwie próbowała uwolnić się od tej, narzuconej jej, roli). Niewątpliwie dlatego też jej imię nie pojawia się w krytycznym eseju Walerija Briusowa o kobietach-poetkach, wśród takich imion jak Zinaida Gippius, 
Nadieżda Teffi, Mirra Łochwicka, czy Adelaida Giercyk (i innych). Autor Me eum esse uważał Zinowjewą-Annibał za osobę "próżną", „wypełnioną od środka cudzymi ideami jak kukła słomą" - tak poeta wyraził się o niej w jednym ze swoich listów do Siergieja Polakowa [Брюсов 1994, 76]. W podobny sposób postrzegały pisarkę i jej twórczość rosyjskie symbolistki, na przykład wspomniana Zinaida Gippius, która równie obrazowo, metaforycznie stwierdziła: „она только повлеклась за другими, туда, куда не один конь поскакал с копытом; г-жа Аннибал не заметила, что копыта у этих коней - раздвоенные..." [Гиппиус 2003]. Niezwykle wymowna w tym kontekście jest wypowiedź Michaiła Kuzmina z komentarzem Nikołaja Bogomołowa o losie niedokończonej powieści Пламенники. Pisze Bogomołow: „Всякий человек, причастный к литературе, который получал текст «Пламенников» (кроме мужа автора), испытывал едва ли не мистический ужас и при всем желании угодить Иванову отказывался уронить марку своего издания. Так было с Мережковским, так было и с Брюсовым” [Богомолов 2009, 39]. „У Брюсова волосы подымались дыбом, когда в редакцию вносили объемистую рукопись Зиновьевского романа" [Богомолов 2009, 39] - wspomina Kuzmin.

Lidia Zinowjewa-Annibał należała do kręgu tych pisarek, które, jak słusznie twierdzi Ewa Komisaruk, „nie roztrząsały spraw ostatecznych. Nie zajmowały ich filozoficzne dywagacje na temat sensu istnienia świata ani wywołująca metafizyczne dreszcze dyskusja nad kwestiami eschatologicznymi”. Ich pasją i celem było „odkrywanie tożsamości kobiety, opis jej egzystencji" [Komisaruk 2009, 11]; być może z tej przyczyny ich utwory często znajdowały się poza tak zwanym kanonem literackim. I rzeczywiście: w dziełach Rosyjskiej Diotymy człowiek - to przede wszystkim kobieta. Czytając utwory prozatorskie i dramatyczne poetki trudno nie zauważyć, jak wiele uwagi poświęca ona kobiecej duszy, kobiecemu światopoglądowi, kobiecej wrażliwości.

Badacze odnotowali fakt, że Zinowjewa-Annibał jako pisarka zaczęła istnieć dopiero $\mathrm{w}$ momencie spotkania $\mathrm{z}$ Wiaczesławem Iwanowem, który wówczas (w $1903 \mathrm{roku}$ ) cieszył się już sławą wybitnego poety. Nieprzypadkowo w usta protagonistki dramatu Кольца (1904) autorka włożyła wyznanie: „Не помню себя до него, какая была. Была ли вовсе? Я - он. Вся в нем” [Зиновьева-Аннибал 2009, 140]. Wczesne dzieła pisarki (przede wszystkim wspomniany dramat) powstały niewątpliwie pod wpływem estetyczno-filozoficznych koncepcji jej męża, w późniejszych (jak powieść Tридuamь mpu урода - 1906) Zinowjewa-Annibał na swój sposób polemizuje z nimi, jak również z wieloma symbolistycznymi zasadami, a nawet odnosi się do nich ironicznie, czyniąc je przedmiotem satyry (na przykład w sztuce Певуиий 
oce - 1906). Nie da się zatem dokonać interpretacji utworów poetki, nie uwzględniając tych wpływów i zależności. Tak też właśnie literaturoznawcy (przede wszystkim Marija Michajłowa, autorka kilku znakomitych artykułów o pisarce i jej twórczości, a także Jekatierina Barkier - autorka jedynej jak dotąd monografii, poświęconej spuściźnie literackiej Zinowjewej-Annibał) badają jej dzieła: w kontekście przejmowania przez poetkę idei Wiaczesława Iwanowa i symbolizmu jako takiego lub polemiki z nimi. Moim celem jest pokazanie antropologii poetyckiej Rosyjskiej Menady jako kobiety, choć tworzącej pod wpływem znakomitego męża, to jednak chcącej zaprezentować w literaturze swój własny, kobiecy, punkt widzenia na człowieka, piękno, miłość, wolność.

Przedmiotem swojej uwagi badawczej czynię uważany za debiut literacki pisarki ${ }^{1}$, wspomniany dramat Кольца. Z dwóch przyczyn: po pierwsze jest to utwór badany (w niewielkim stopniu, jak i cała jej twórczość) jak dotąd dość jednostronnie (jako odzwierciedlenie Iwanowowskich koncepcji miłości soborowej, kryzysu indywidualizmu itd.); po drugie - wydaje się on najbardziej ,antropologicznym” ze wszystkich tekstów Zinowjewej-Annibał, a koncepcje w nim zawarte pisarka rozwija w swoich późniejszych dziełach.

Ten symbolistyczny dramat, powstały w oparciu o idee Wiaczesława Iwanowa i zachowujący wszelkie zasady i kanony symbolizmu, ujrzał światło dzienne w 1904 roku w Moskwie [Богомолов 2004, 293-297], wywołując skrajne emocje i oceny. Z jednej bowiem strony sztuka uważana była za poważny dramaturgiczny eksperyment, który w swoim czasie zainteresował Wsiewołoda Meyerholda, z drugiej natomiast zarzucano јеј „повторы, растянутость, пафосные, витиеватые монологи, пестреющие словами «безначальность», «мироздания», ломкую корявость ремарок" [Михайлова 2009, 17] itp. Jego interpretacja nie jest sprawą prostą, zważywszy na fakt, że już współcześni akcentowali niezrozumiałość dramatu, niemożność deszyfracji licznych zawartych w nim symboli, do których „kluczy” nie ma nawet w napisanej przez Wiaczesława Iwanowa obszernej przedmowie: „Первое, за что упрекнули автора Колеи была «непонятность» драмы, невозможность расшифровки ее символов, «ключей» к которым не дает даже предпосланное Вяч. Ивановым предисловие" [Баркер 2003, 51]. Po części klucze można jednak znaleźć zarówno w refleksji estetyczno-filozoficznej (i w twórczości) samego autora Cor ardens, jak i innych poetów

1 W rzeczywistości pierwszym, napisanym jeszcze przed spotkaniem z Wiaczesławem Iwanowem, utworem Zinowjewej-Annibał było opowiadanie Неизбежное зло [Михайлова 2009, 16]. 
i myślicieli przełomu wieków, dlatego analiza tekstu dramatu implikuje konieczność odwołań do nich.

Najprościej rzecz ujmując, Кольца to dramat o miłości, pojmowanej w duchu filozofii miłości soborowej Wiaczesława Iwanowa. Marija Michajłowa uważa, że „В этой драме сплелись идеи отречения и самоотречения, отказа от уединенности и необходимости жертвы. Аннибал-писательница прослеживала все возможные варианты любовного чувства любовь-страсть, любовь-упоение, любовь-ослепление, любовь-жертвенность, любовь-дружбу - и наделяла ими живых и мучающихся героев" [Михайлова 2004]. Z kolei cytowana już Jekatierina Barkier traktuje analizowany dramat jako realizacje „dionizyjskiej mitotwórczości” pisarki [Баркер 2003, 36 i dalej], co jednak, jak się wydaje, wcale nie jest tak oczywiste i jednoznaczne. Ma ona natomiast niewątpliwie rację (podobnie jak inni badacze, na przykład wspomniana Michajłowa), pisząc, że u podstaw filozoficznej koncepcji dramatu leży Iwanowowska idea przekraczania granic indywidualizmu [Баркер 2003, 36].

Zinowjewa-Annibał kreuje w swoim utworze swoisty mit (czy też raczej automit) o Bachantce, Menadzie, kobiecie, która, wyrzekając się wszystkiego, co ją ogranicza, podejmuje wysiłek wzniesienia się ku temu, co uniwersalne. Bowiem, jak pisał Iwanow, „подвиг восхождения - подвиг разлуки и расторжения, утраты и отдачи, отрешения от своего и от себя ради дотоле чуждого и ради себя иного" [Иванов 2007, 40]. Główną postacią dramatu jest Agłaja², szczęśliwa żona i matka. Z drugim mężem Aleksiejem łączy ją szczególny rodzaj uczucia: głęboka, szczera, oparta na wzajemnym zaufaniu miłość. Kobieta ma jednak świadomość, że kochając Aleksieja nie może mieć go wyłącznie dla siebie. Dlatego w imię miłości absolutnej próbuje uwolnić się od egoizmu i indywidualizmu i, choć przychodzi jej to z trudem i wymaga ogromnego poświęcenia, pragnie podzielić się swoim ukochanym z innymi. Taki rodzaj miłości sama autorka (wraz z mężem) chciała realizować w życiu, o czym powszechnie wiadomo; taki też typ uczucia reprezentuje protagonistka dramatu, przeciwstawiając go miłości-namiętności, której ucieleśnieniem jest jej były mąż Wania. To on uosabia w tekście ideał męskości, kojarzony z poszukiwaniem tego, co osiągalne, zaś sama Agłaja, jak można sądzić, stanowi ucieleśnienie kobiety w Iwanowowskim rozumieniu (zob. esej О достоинстве женщинь - 1908): miłującej wolność i potrafiącej otworzyć się na to, co kosmiczne, nieznane, powszechne i nieograniczone [Иванов 2007, 264]. Jednak, jak pisze poeta: „Ни одна великая

2 Imię to niewątpliwie odsyła do bohaterki Idioty. Związkom dramatu Zinowjewej-Annibał z Dostojewskim poświęcona zostanie odrębna praca. 
идея не торжествует без подвигов отречения. [...] Так и женщина, если она хочет возвыситься и восторжествовать, должна найти в себе силы для своеобразного аскетизма” [Иванов 2007, 267]. I dalej: „Она должна практически утверждать и осуществлять в любви только абсолютное" [Иванов 2007, 268].

Bohaterka dramatu Zinowjewej-Annibał, uosabiająca taki właśnie, symbolistyczny, ideał kobiecości, jest postacią w pewien sposób wewnętrznie rozdartą $^{3}$, reprezentuje typ kobiety fatalnej, toczącej nieustanną wewnętrzną walkę. Nieprzypadkowo w jej otoczeniu (i w wyglądzie) od samego początku dominują dwa kolory o ambiwalentnej symbolice: biel i czerwień. Ważne znaczenie posiadają pojawiające się (już w pierwszym akcie utworu) w mieszkaniu Agłai białe lilie, purpurowe róże, czerwone maki i - dodatkowo - żółte tulipany, które w określony sposób charakteryzują kobietę. Przypomnę: białe lilie w tradycji chrześcijańskiej stanowią atrybut Matki Boskiej (dodatkowo: biel to symbol czystej, sakralizowanej miłości) [Lurker 1989, 116; Kopaliński 1990, 199-200], czerwień i purpura są znakami namiętności [Kopaliński 1990, 55); w połączeniu z różami stają się atrybutem Afrodyty jako bogini miłości namiętnej i występnej [Kopaliński 1990, 363); czerwone maki natomiast (pojawiające się w tekście kilkakrotnie) są, zgodnie z tradycją, oznaką śmierci [Токарев 1982, 90]. Z kolei barwa żółta w swej warstwie symbolicznej oznacza zdradę i fałsz [Kopaliński 1990, 506], zatem jej obecność w otoczeniu protagonistki można potraktować właśnie jako znak zdrady. Bogactwo i ambiwalencja semantyczna tych motywów-symboli, związanych z postacią głównej bohaterki utworu, mogą wskazywać na wspomnianą złożoność i niejednoznaczność tej figury, którą należałoby postrzegać właśnie jako femme fatale.

Zinowjewa-Annibał czyni swoją bohaterkę uosobieniem piękna. Wpisując się w symbolistyczny kanon myślenia o pięknie, posiadający swe korzenie w filozofii Platona (by odwołać się choćby do Uczty), a wyrażony na przykład w pracach Wiaczesława Iwanowa ${ }^{4}$, pisarka łączy je z pojęciem miłości i dobra, a także - szczęścia. „Ты красива, Аглая, этой жизнью. Красиво видеть столько жизни и доброты. Это редко бывает. Ты счастлива, оттого ты добра. [...] Счастье делает человека красивым, добрым... цельным" [Зиновьева-Аннибал 2009, 138] - te słowa wkłada autorka w usta innej bohaterki dramatu, Anny, podkreślając tym samym ponadprzeciętność

3 Tego rodzaju ambiwalencję dostrzegali współcześni (np. Nikołaj Bierdiajew) w osobie Lidii Zinowjewej-Annibał [Эконен 2011, 140-141].

4 Por. nр.: „Явственно внутреннее тожество красоты и добра. Ибо скрытое начало добра - то же, что начало красоты [...]" [Иванов 2007, 43]. 
i wyjątkowość Agłai. Ta ponadprzeciętność pozwala jej w sposób odmienny niż pozostali bohaterowie patrzeć na rzeczywistość, na miłość swoją własną i na miłość w ogóle. Ta ponadprzeciętność sprawia też, że Agłaja jest kobietą, która poszukuje wolności i nie boi się dokonywać trudnych życiowych wyborów.

To właśnie poczucie zniewolenia i tęsknota za wolnością stają się przyczynkiem do porzucenia przez nią pierwszego, niewiernego męża. Wiążąc się z ukochanym Aleksiejem, kobieta na chwilę odzyskuje wolność (czy też raczej - złudzenie wolności - o czym dalej) - w miłości. W jej wypowiedziach dominuje symbolika związana z przestrzenią, morzem, światłem. Por.: „Солнце уже в саду! А там, за соснами, чувствуешь море! [...] простор чуется где-то близко, в самом воздухе. [...] О, как нам было хорошо у моря! Волны!... У самых волн мы ходили часами - они набегают, отбегают и снова..." [Зиновьева-Аннибал 2009, 139]. Jednakże ta nieograniczona przestrzeń znajduje się niejako poza zasięgiem bohaterki. Pierwsza scena dramatu, podczas której Agłaja charakteryzuje swoją miłość do męża i podczas której również dowiaduje się o jego zdradzie, rozgrywa się $\mathrm{w}$ zamkniętym pomieszczeniu z oknem. W momencie, kiedy bohaterka szeroko otwiera okno, do pokoju wdzierają się ostre i kłujące gałązki sosen. Drzewa, ciemną ścianą okalające dom, spełniają rolę granicy, oddzielającej zamknięta przestrzeń, w jakiej dosłownie i symbolicznie egzystuje Agłaja, od otwartej przestrzeni morza i światła, którą kobieta jedynie czuje dzięki promieniom słońca przebijającym się przez ścianę sosen. Znamienne są jej słowa: „[...] вся комната так странно освещена. Сквозь сосны это как огонь золотой! Гляди, гляди: вот солнце. Солнце уже в саду! А там, за соснами - чувствуешь море! Мне всегда кажется, можно чувствовать море, и не видя его: простор чуется где-то близко, в самом воздухе" [Зиновьева-Аннибал 2009, 139]. Świadczą one o tym, że Agłaja jednak nie jest całkiem wolna, choć wolność znajduje się na wyciągnięcie ręki.

Świadomość zniewolenia pojawia się tuż po tym, jak bohaterka dowiaduje się o zdradzie ukochanego Aleksieja, o czym świadczy jej gorzka refleksja: „Вот море, ветер, вот чайка кричит, а я не могу” [Зиновьева-Аннибал 2009, 163]. Swoją sytuacje porównuje do sytuacji człowieka zamkniętego w ciemnicy: „Но я в себе заключена, и из моей темницы, темной темницы двери нет... - окно, одно узко прорезанное окно. А... а... а... Чтобы выйти из своей темницы, надо разбить себя..." [Зиновьева-Аннибал 2009, 166]. Ciemnicy z wąskim oknem jako symbolicznemu więzieniu przeciwstawiony jest $\mathrm{w}$ dramacie motyw oceanu świata (мировой океан), z którym bohaterka pragnie połączyć swoją duszę. Pierwszym krokiem ku wolności jest jej wyjście z domu nad brzeg morza w drugim akcie utworu. Tu 
również niezwykle ważną rolę odgrywa przestrzeń. Zinowjewa-Annibał, wykorzystując symbolistyczną zasadę correspondance, pokazuje walkę toczącą się w duszy bohaterki. Jej symbolem jest nadciągająca burza i jej zwiastuny: niespokojne fale, rozbijające się o brzeg, światło słoneczne, które staje się ciężkie, różowe obłoki (czerwień i biel zlewają się tu ze sobą tworząc barwę różową), czarne chmury o „srebrzystoognistych” brzegach oraz słyszany z oddali grzmot. To właśnie wtedy, w takiej scenerii, w otwartej przestrzeni Agłaja jako uosobienie Miłości silniejszej od śmierci, kochająca swojego męża ponad wszystko, zaczyna zdawać sobie sprawę z tego, że ta - egoistyczna w jej pojęciu - miłość ją ogranicza, staje się dla niej ciężarem i więzieniem.

Jej uczucie do męża jest bowiem w określony sposób uporządkowane, posiada swój rytm, przyrównywany przez bohaterkę do rytmu morskich fal; jest naturalnym stanem duszy [Зиновьева-Аннибал 2009, 140], opartym na jedności (całościowości). I... jako takie właśnie skazane jest na niepowodzenie. Pisarka w pewien sposób dokonuje przewartościowania popularnej wśród symbolistów Platońskiej koncepcji miłości-Erosa, zakładającej właśnie androgyniczną jedność oraz bazującej na tworzeniu w pięknie. W dramacie uczucie istniejące pomiędzy małżonkami to, wedle słów bohaterki, „Великая, цельная, верная, опорная любовь, что выше отчаяния, выше боли, дальше смерти... [...] Да и любовь ли? - просто чудо, чудо слияния! Из двух чудесно рождается одно, третье, таинственное, единое третье" [Зиновьева-Аннибал 2009, 140]. Jednak ta oto, pojęta w duchu platońskim jako tęsknota za androgyniczną jednością i za tworzeniem w pięknie, miłość zniewala człowieka (tu: kobietę) i ogranicza, zaciera świadomość własnego $J a$ i nie pozwala odnaleźć w sobie pierwiastka kosmicznego. W takim świetle szczególne znaczenie zyskują cytowane już słowa bohaterki: „Не помню себя до него, какая была. Была ли вовсе? Я - он. Вся в нем”. One również odsyłają do androgynicznego aspektu miłości [o srebrnowiecznej „filozofii” androgynizmu zob. Рябов 1999, 166-173]. Jednak Agłaja jednocześnie przyznaje tu, że przed spotkaniem z Aleksiejem właściwie nie istniała; to on ją niejako wykreował, w wyniku czego nie może ona już istnieć bez niego. Bez wątpienia znajdujemy tu aluzję do symbolistycznego myślenia o kobiecie jako pierwiastku pasywnym, zaś o mężczyźnie - jako twórcy, kreatorze, tym, który, wedle słów Bierdiajewa, „оформляет, дисциплинирует, организует" [Бердяев 1990, 210].

Taki rodzaj uczucia i taka zależność pomiędzy małżonkami powodują, że kobieta nie może czuć się wolna, a jej szczęście jest złudne. Agłaja w swoich wypowiedziach niejednokrotnie (świadomie lub nie) wskazuje na erotyczne zabarwienie miłości, by przywołać choćby następujące słowa: „Женщина так скоро и некрасиво стареет, и любовь вся связана с телом и его 
молодостью. [...]" [Зиновьева-Аннибал 2009, 141]. Oddając się całkowicie drugiemu człowiekowi i dostrzegając w tym oddaniu symptomy zniewolenia, kobieta, jeszcze nieświadoma zdrady męża, zaczyna odczuwać strach: „Страшно от слишком блаженной любви. И от страха бросаешься один к другому - да? Да, Анна? Теснее, теснее... даже бешенство, дикость какая-то есть в таком тесном объятии. Так, Анна, так? Может быть, это и есть предчувствие смерти - такая страсть? Такая насильственная отдача себя до конца, до конца и поиски конца, потому что все кажется - еще тебя осталось, еще не все отдано от тебя любимому... И боль [...]" [Зиновьева-Аннибал 2009, 155].

Agłaja wie, że ziemska miłość naznaczona jest bólem i śmiercią. Eksplikację tej myśli znajdujemy nie tylko w jej losie, ale także w życiu jej owdowiałej bratowej Anny, nieustannie balansującej pomiędzy miłością i namiętnością, szczęściem i bólem, życiem i śmiercią. Anna traci ukochane dzieci, bezpośrednio po namiętnym akcie miłosnym ginie jej mąż, a następnie, po tym jak Aleksiej zostawia dla niej żonę, on również umiera. O nieustannej walce życia ze śmiercią w sposób obrazowy mówi opowieść Anny o akwarium z żyjątkami, które zniszczył mogilny robak: „Это был могильный червяк, он съел всю жизнь. Когда была жизнь, его не было, но когда началось гниение, он родился и пожрал живое, и остался один" [Зиновьева-Аннибал 2009, 153]. Ta symboliczna opowieść tłumaczy też poniekąd los pary protagonistów dramatu: w momencie zdrady Aleksieja zaczyna się proces gnilny w małżeństwie (i całym życiu) Agłai, pojawia się w nim „robak śmierci” i los bohaterów wydaje się przesądzony. Jedynym ratunkiem może być miłość. Jak pisze w związku z dramatem Кольиа Michajłowa: „Человек мечтает зажечь факел, который осветил бы его Я. Этот свет-огонь - Любовь. Но земля-любовь поругана изначала смертью. Победить смерть и тление можно только преображением через страдание, через мировое сострадание" [Михайлова 1994, 144-156].

Dlatego bohaterka nie walczy o swoją miłość i nie broni się przed cierpieniem. Symbolem uczucia, które stało się dla niej więzieniem, są tytułowe obrączki. „Твоя любовь - железное кольцо. [...] Твоя любовь сковала себе свой круг; вот почему ты слепа" [Зиновьева-Аннибал 2009, 178] - uświadamia Agłaję Wania. I kobieta przyznaje mu rację: „Я слепа. Моя любовь в плену. Как пленной снести пленную любовь? [...] Любовь ослепила мои глаза " [Зиновьева-Аннибал 2009, 178, 181]. Pragnąc wyzwolić się od tego więzienia egoistycznej miłości i indywidualizmu, Agłaja chce otworzyć się na miłość kosmiczną, na miłość wszechświata: „Мы не можем быть двое, не должны смыкать кольца, мертвым зеркалом отражать мир. Мы - мир. [...] Океану любви наши кольца любви! [...] Не надо жа- 
леть тесных милых колечек" [Зиновьева-Аннибал 2009, 198, 199, 209]. Motyw ten w tekście dramatu symbolicznie został wyrażony przez poszerzanie przestrzeni, w której egzystuje bohaterka: początkowo akcja rozgrywa się w domu, później przenosi się na brzeg morza, zaś wydarzenia w trzecim, ostatnim akcie utworu rozgrywają się na statku płynącym po oceanie. „Из Дома - на Берег Моря - а затем в бескрайнюю открытость Океана - вот путь освобождения души человеческой, устремленной к Космосу, Неведомому, Вечности, Свободе, Любви" - komentuje wspomniany chwyt Michajłowa [Михайлова 1994].

Tak też protagonistka utworu Zinowjewej-Annibał pojmuje wolność: jako „kosmiczną jedność”, zjednoczenie się z twórczym duchem wszechświata, ale także jako umiejętność odnalezienia i dostrzeżenia w sobie pierwiastka kosmicznego. „В людях и дух космоса, и душа покорного слезам и радости человека" [Зиновьева-Аннибал 2009, 140] - te słowa Agłai korespondują z myślą filozoficzną Nikołaja Bierdiajewa, wyrażoną między innymi w Sensie twórczości, a dotyczącą istniejącej w człowieku zasady męskiej antropologicznej oraz żeńskiej - kosmicznej [Bierdiajew 2001, 155]. W ostatnim akcie dramatu bohaterka wyraża pragnienie i gotowość otwarcia się na miłość kosmiczną: „Тогда моя грудь откроется. (Громко.) Вся моя грудь откроется, и я потеряю себя, и весь мир войдет в меня пылающей любовью” [Зиновьева-Аннибал 2009, 199]. Dalej Agłaja przyznaje: „Когда грудь так через любовь открылась - вошел весь мир в мою смертную грудь" [Зиновьева-Аннибал 2009, 200]. Warto, w związku z tym, przytoczyć jako kontekst interpretacyjny słowa znanego wiersza autora Cor ardens z tomu Кормчие звезды: „Душа объятия раскрыла / Горит, и напрягает крыла" [Иванов 1995, 77]5. Tak oto, zaprezentowaną w dramacie koncepcją miłości autorka wpisuje się nie tylko w estetykę Wiaczesława Iwanowa, uważającego, że „Все нужно принять в себя, как оно есть в великом целом, и весь мир заключить в сердце" [Иванов 2007, 46], ale i symbolizmu jako takiego. Można by tu również przypomnieć myśl innego czołowego przedstawiciela kierunku - Walerija Briusowa, dotyczącą świadomości artysty, że mieści on w sobie cały świat („весь мир во мне”) [Брюсов 2010, 176].

Agłaja wierzy, że otwierając się na świat, na ocean miłości, może stać się wolna. Pojawiający się w jej wypowiedzi (w ostatnim akcie) mitologem skrzydeł jako symbolu wolności („Каждый - всем. Раскрой грудь люб-

5 Ten fragment liryku poety przytacza także, w związku z rozważaniami o Erosie, Maria Cymborska-Leboda [Cymborska-Leboda 2002, 39]. 
ви! Легче, легче. Вырастут крылья!" [Зиновьева-Аннибал 2009, 188]), obecny również w wyżej przywoływanym wierszu Iwanowa, każe powrócić do obrazu ptaka - mewy z aktu drugiego (przypomnę: „вот чайка кричит, а я не могу"). Ten sam motyw pojawia się w końcówce utworu: tutaj mewa jako uosobienie swobody, krążąc nad oceanem, naśmiewa się z losu bohaterki („чайка в высоте насмеется хохотом на мою тоску!” [Зиновьева-Аннибал 2009, 205]). I Agłaja wie, że niebawem okręt dobije do brzegu („Koрабль встретит берег” [Зиновьева-Аннибал 2009, 205]) - a więc, że ocean, mimo ogromu, również ma swój kres. Ucieleśnieniem wolności są także delfiny, beztrosko igrające w wodzie [Зиновьева-Аннибал 2009, 204], lecz zaraz potem przed oczami bohaterów pojawia się ciało martwego delfina, bezwolnie unoszace się na falach [Зиновьева-Аннибал 2009, 208]. To wszystko zdaje się zwiastować przybliżający się tragiczny koniec. Marzenia bohaterki o otwarciu się na ocean miłości, o połączeniu się z duszą świata, o wolności, okazały się jedynie mrzonkami, zaś wolność, którą przez chwilę zdawała się odczuwać Agłaja - ułudą. Mając świadomość, że miłość nie jest niczyją własnością ( „Любовь, Анна, тоже никому не принадлежит” [Зиновьева-Аннибал 2009, 200]) i oddając męża Annie, kobieta w pewnym sensie odzyskała wolność, lecz okazała się do tej wolności nieprzygotowana, zbyt słaba: „Анна! Я к тебе с благодарностью: ты мне дала великую свободу. А... а... мне не снести великой свободы" [Зиновьева-Аннибал 2009, 196]. Otwarła wprawdzie swoją duszę, lecz jej serce ciągle pozostało uwięzione w kręgu miłości do Aleksieja: „А... грудь раскрыта, но сердце сжато в своем кольце" [Зиновьева-Аннибал 2009, 201].

Tak oto bohaterce ostatecznie nie udaje się całkowicie wyzwolić z więzienia swojego egoizmu i indywidualizmu i zrealizować postulatu „erotyczno-mistycznego kolektywizmu" [Михайлова 2004], podobnie jak nie udało się to samej autorce (niepowodzeniem zakończyły się związki Annibał - Iwanow - Gorodieckij; Annibał - Iwanow - Sabasznikowa). Myśl o niemożności osiągnięcia tego rodzaju wolności, która w dramacie pojawia się niejako implicite, z pełną siłą wybrzmi w powieści Тридиать три урода.

\section{Literatura}

Bierdiajew N., 2001, Sens twórczości. Próba usprawiedliwienia cztowieka, przeł. H. Paprocki, Kęty.

Komisaruk E., 2009, Od milczenia do zamilknięcia. Rosyjska proza kobieca na poczatku XX wieku. Wybrane aspekty, Wrocław.

Kopaliński W., 1990, Stownik symboli, Warszawa. 
Lurker M., 1989, Stownik obrazów i symboli biblijnych, przeł. K. Romaniuk, Poznań.

Barker E. N., 2001, Dionisijskij simvol serebrânovo veka: tvorčestvo L. D. Zinov'evoj-Annibal, avtor. diss. na soisk. uč. st. k.f.n. [Баркер Е. Н., 2001, Дионисийский символ серебряного века: творчество Л. Д. Зиновьевой-Аннибал, автор. дисс. на соиск. уч. ст. к.ф.н., Санкт-Петербург], [online], http://www.dissercat.com/content/dionisiiskii-simvol-serebryanogo-vekatvorchestvo-l-d-zinovevoi-annibal, [25.01.2018]

Barker E. N., 2003, Tvorčestvo Lidii Zinov'evoj-Annibal, Sankt-Peterburg. [Бapкер Е. Н., 2003, Творчество Лидии Зиновьевой-Аннибал, Санкт-Петербург.]

Berdâev N., 1990, Filosofiâ neravenstva, Moskva. [Бердяев Н., 1990, Философия неравенства, Москва.]

Bogomolov N. A., 2004, Ot Puškina do Kibirova. Stat'i o russkoj literature, preimuŝestvenno o poèzii, Moskva. [Богомолов Н. А., 2004, От Пушкина до Кибирова. Статьи о русской литературе, преимущественно о поэзии, Москва.]

Bogomolov N. A., 2009, ...I drugie dejstvû̂ŝie lica, [v:] Vâčeslav Ivanov, Lidiâ Zinov'eva-Annibal. Perepiska 1894-1903, t. 1, podgot. teksta D. O. Colodkoj, N. A. Bogomolova pri učastii M. Vahtelâ, Moskva, s. 22-59. [Богомолов Н. А., 2009, ...И другие действующие лича, [в:] Вячеслав Иванов, Лидия Зиновьева-Аннибал. Переписка 1894-1903, т. 1, подгот. текста Д. О. Солодкой, Н. А. Богомолова при участии М. Вахтеля, Москва, c. $22-59$.]

Brûsov V. Â., 1994, Perepiska s S. A. Polâkovym (1899-1921), publ. N. V. Kotreleva, L. K. Kuvanovoj i I. P. Âkir, „Literaturnoe Nasledstvo”, t. 98: Valerij Brûsov i ego korrespondenty, kn. 2, otv. red. N. A. Trifonov, Moskva, s. 5-136. [Брюсов В. Я., 1994, Переписка с С. А. Поляковылм (1899-1921), публ. Н. В. Котрелева, Л. К. Кувановой и И. П. Якир, "Литературное Наследство", т. 98: Валерий Брюсов и его корреспонденты, кн. 2, отв. ред. Н. А. Трифонов, Москва, с. 5-136.]

Brûsov V. Â., 2010, Svâŝennaâ žertva, [v:] Sintetika poèzii. Mysli i zamečaniâ, Moskva, s. 173-178. [Брюсов В. Я., 2010, Священная жертва, [в:] Синтетика поэзии. Мьисли и замечания, Москва, с. 173-178.]

Cymborska-Leboda M., 2002, Ėros v Tvorčestve Vâčeslava Ivanova. Na puti $k$ filosofii lûbvi, Lublin. [Cymborska-Leboda M., 2002, Эрос в творчестве Вячеслава Иванова. На пути к философии любви, Lublin.]

Èkonen K., 2011, Tvorec. Sub"ekt. Ženŝina. Strategii ženskogo pis'ma v russkom simvolizme, Moskva. [Эконен K., 2011, Творещ. Субъект. Женщина. Стратегии женского письма в русском символизме, Москва.]

Gippius Z. N., 2003, Bratskâa mogila, [v:] Sobranie sočinenij, t. 7: My i oni. Literaturnyj dnevnik. Publicistika 1899-1916, Moskva. [Гиппиус 3. Н., 2003, Братская могила, [в:] Собрание сочинений, т. 7: Мыл и они. Литературный дневник. Публииистика 1899-1916, Москва], [online], http://az.lib. ru/g/gippius_z_n/text_1907_bratskaya_mogila.shtml, [05.11.2018]. 
Ivanov V. I., 1995, Noč’ v pustyne, [v:] Stihotvoreniâ. Poèmy. Tragediâ, kniga 1, sost., podgot. teksta i primeč. R. E. Pomirčego, Sankt-Peterburg, s. 76-82. [Иванов В. И., 1995, Ночь в пустыне, [в:] Стихотворения. Поэмы. Трагедия, книга 1, сост., подгот. текста и примеч. Р. Е. Помирчего, Санкт-Петербург, с. 76-82.]

Ivanov V. I., 2007, Simvolika èstetičeskih načal, [v:] Po zvezdam. Borozdy i meži, vstup. stat'â, sost. i primeč. V. V. Sapova, Moskva, s. 39-46. [Иванов В. И., 2007, Символика эстетических начал, [в:] По звездам. Борозды и межи, вступ. статья, сост. и примеч. В. В. Сапова, Москва, с. 39-46.]

Mihajlova M. V., 1994, Strasti po Lidii. Tvorčeskij portret L. Zinov'evoj-Annibal, „Preobraženie. Russkij feministskij žurnal” nr 2, s. 144-156. [Михайлова М. В., 1994, Страсти по Лидии. Творческий портрет Л. Зиновьевой-Аннибал, "Преображение. Русский феминистский журнал" нр 2, c. 144-156], [online], http://www.a-z.ru/women/texts/mihailrddd-e.htm [20.08.2018]

Mihajlova M. V., 2004, Žizn' i smert' Russkoj Menady, „Vokrug sveta” 1 maâ [Михайлова М. В., 2004, Жизнь и смерть Русской Менады, "Вокруг света" 1 мая], [online] http://www.vokrugsveta.ru/vs/article/360, [30.07.2018]

Mihajlova M. V., 2009, „Baby s p'esami...”v èpohu modern, [v:] Ženskâ̂ dramaturgiâ Serebrânogo veka, sost., vstup. stat'â i komment. M. V. Mihajlovoj, Sankt-Peterburg, s. 5-64. [Михайлова М. В., 2009, "Бабы с пьесами..." в эпоху modern, [в:] Женская драматургия Серебряного века, сост., вступ. статья и коммент. М. В. Михайловой, Санкт-Петербург, c. $5-64$.

Râbov O., 1999, Russkâ̂ filosofiâ ženstvennosti (XI-XX veka), Ivanovo. [Рябов О., 1999, Русская философия женственности (XI-XX века), Иваново.]

Tokarev S. A. (red.), 1982, Mify narodov mira, t. 2, Moskva. [Токарев С. А. (ред.), 1982, Мифы народов мира, т. 2, Москва.]

Zinov'eva-Annibal L., 2009, Kol'ca, [v:] Ženskâ̂ dramaturgiâ Serebrânogo veka, sost., vstup. stat'â i komment. M. Mihajlovoj, Sankt-Peterburg, s. 135-210. [Зиновьева-Аннибал Л., 2009, Кольиа, [в:] Женская драматургия Серебряного века, сост., вступ. цтатья и коммент. М. Михайловой, СанктПетербург, с. 135-210.]

\title{
ANTHROPOLOGICAL ASPECT OF LYDIA ZINOVIEVA-ANNIBAL'S WRITINGS. IMAGE OF WOMAN IN THE DRAMA THE WEDDING RINGS
}

\author{
S U M M A R Y
}

Key words: Lydia Zinovieva-Annibal, The Wedding Rings, symbolism, woman, drama

The article is devoted to an attempt at analyzing the symbolist drama by Lydia Zinovieva-Annibał Kольца (The Wedding Rings) in connection with the image of 
woman created in it. The writer creates a woman renouncing what restricts her (individualism, egoism) and trying to rise to what is universal, to achieve freedom in this way. The protagonist is the incarnation of beauty, good and love, understood in the spirit of Plato's philosophy as an androgynic unity. The poet polemicizes with Plato's idea, showing that such a love restricts humans and becomes a prison for them. The title wedding rings constitute that kind of a feeling. Giving her husband up to another woman, the protagonist wants to open herself to the cosmic love, to the ocean of love in this way and regain freedom. However, she turns out to be unprepared and too weak for that freedom. She manages to open her soul, but her heart still remains trapped in the circle of her love towards her husband. 